\title{
These Great Urbanist Games: New Babylon and Second Life
}

\author{
Thomas M. Malaby, \\ University of Wisconsin, Milwaukee, USA
}

\begin{abstract}
Constant Nieuwenhuys (aka Constant), twentiethcentury painter and architect and founding member of the Situationist International, is perhaps best known for his ambitious project of unitary urbanism, New Babylon, on which he worked from 1958 until 1973. This proposed city (which would, theoretically, cover the globe) was intended to prompt all people to express their creativity through their constant reconfiguration of its open and malleable living space. Explicitly designed for homo ludens, in it social life was to be constituted by architectural play. But, as Mark Wigley has noted, "play was the whole point of New Babylon but not its mode of production". As designer of this universalizing and revolutionary play-space, Constant's role entailed the contrivance of open-endedness, and thus implicitly relied upon the very artistic authority that the Situationists had rejected (Constant left the Situationists in 1960). Today, 50 years after he began his project, we can witness similar ideals and contradictions in the virtual world Second Life, an architected social space which also claims to be an infinitely malleable forum for creative expression. In this article the author traces to what extent the ideological foundations of both of these projects can be linked to postwar attitudes toward technology and authority on both sides of the Atlantic, and explores how they each draw on notions of play in distinctive ways. Arriving at the same ideals and contradictions via separate but related paths, New Babylon and Second Life reflect two responses to the challenges of design and post-bureaucratic hopes for the productivity of play.
\end{abstract}

Keywords: play, virtual worlds, game design, technology, Second Life, Constant, New Babylon

Michel de Certeau, the French social theorist perhaps most attuned to the fraught nature of the relationship between designed spaces and everyday practices, took a moment in his landmark L'invention du quotidian, Vol. 1: Arts de faire (1980, translated by Steven Randall in 1984 as The practice of everyday life) to muse about the rise of technology and its possible saturation of everyday experience, and what that meant for the future of the city. He imagined that the proliferation of technology in an unbounded sense would dissolve what had been a distinction between "proper" institutional spaces and the unbounded spaces of the quotidian. He continued (de Certeau, 1984, p. 40):

The system in which [people] move about is too vast to be able to fix them in one place, but too constraining for them ever to be able to escape from it and go into exile elsewhere. There is no longer an elsewhere. Because of this, the "strategic" model is also transformed, as if defeated by its own success; it was by definition based on the definition of a "proper" distinct from everything else; but now that "proper" has become the whole. It could be that, little by little, it will exhaust its capacity to transform itself and constitute only the space ... in which a cybernetic society will arise, the scene of the Brownian movements of invisible and innumerable tactics. One would thus have a proliferation of aleatory and indeterminable manipulations within an immense framework of socioeconomic constraints and securities: myriads of almost invisible movements, playing on the more and more refined texture of a place that is even, continuous, and constitutes a proper place for all people. Is this already the present or the future of the great city?

This question of how technology may make imaginable a new kind of environment, characterized by a kind of totality that contains infinite improvisation, finds striking and concrete expression in two "urbanist" projects, one never realized and one host to hundreds of thousands of people today. New Babylon, the postwar unitary urbanist project of the Dutch painter Constant Nieuwenhuys (known as "Constant"), and Second Life, the virtual world made by Linden Lab of San Francisco, each lie almost exactly 23 years to either side of de Certeau's writing. His description of the totalizing containment of the new city, and how it would provide a context for the "Brownian movements of invisible and innumerable tactics", serves equally well for either project, at least in their utopian aims. Both of them sought to make use of design and technology to accomplish a seeming contradiction: to contrive and control a space for utterly free and self-governing action. In doing so, they each - though seemingly entirely unrelated in their histories (and apparently unknown to de Certeau) - drew upon 
related notions of play and creativity - productive play - and prompted strikingly similar conundra of governance and authority.

Constant, who was a founding member of the Situationist International with Guy Debord, worked on New Babylon from 1958 until 1973. This proposed city (which would, theoretically, cover the globe) was intended to prompt all people to express their creativity through their constant reconfiguration of its open and malleable living space. Explicitly designed for homo ludens, in this "great urbanist game" (de Zegher, 2001, p. 10) social life was to be constituted by architectural play. But, as Mark Wigley has noted, "play was the whole point of New Babylon but not its mode of production" (2001, p. 27). As designer of this universalizing and revolutionary play-space, Constant's role necessitated the contrivance of openendedness, and thus implicitly relied upon the very artistic authority that the Situationists had rejected (Constant left the Situationists in 1960). In Second Life, an architected social space online which also claims to be an infinitely malleable forum for creative expression, the same tension is in place. Linden Lab, its creator, has made a product that it is supposed to make itself, based upon ideals of universal access and unconstrained creativity and concrete techniques of game design, but Linden Lab also confronted the designer's contradiction of occupying a position of deeper access to Second Life's code, to what is "under the hood".

In what follows I briefly draw some of these connections in order to spark thinking about the nature of design under post-bureaucratic imaginings, and how these cases illuminate the different influence of play on that effort on both sides of the Atlantic. I hasten to note that in doing this I am delving into an area not originally my own - not being, to take just one more fitting possibility, an architectural historian. As a cultural anthropologist who studied the making of Second Life by the small group of people at Linden Lab in San Francisco, I grew interested in connecting such efforts to the broader arc of thinking about design and certain strands of architectural thought. In encountering Constant's New Babylon I was struck by the depth of parallels in the cases and intrigued to find out what might be learned from considering how their differences reflect their culturo-historical situations, so I offer the following connections in the hope that it may be helpful for beginning to think about how notions of play as a productive force influence design, but in ways that reflect culturo-historic specificities. Such a conversation about architecture, design, play, and technology may further help us to understand the histories and ideals behind the digital architectures that increasingly mediate our everyday actions.

\section{CONSTANT AND NEW BABYLON}

The scholarship on Constant is distinguished, but far from extensive. In 1999 his drawings from the project were the centerpiece of an exhibit about New Babylon at the Drawing Center in New York, and the center also hosted a symposium which brought a number of scholars on Constant together, as well as
Constant himself, who was in attendance (he died in 2005). In what follows I rely heavily on the volume published thereafter, which includes many images from the exhibit along with participants' essays and an interview with Constant (de Zegher and Wigley, 2001). There are other works that more directly trace the influence of Constant and the Situationists on architecture and urban planning (see especially Borden and McCreery, 2001), but my interest here is shaped more by the specific parallels between New Babylon and Second Life.

What was New Babylon? The design for the city called for two planes, one above the other, with living space in between. Both planes would be suspended above the ground (via cables from large columns that dot the New Babylon landscape), allowing for traffic underneath, along the ground, and with the top of the upper plane available for aircraft use. The city was to expand not as one ever larger shape, but via multiple, networked corridors of this interconnected space (Figure 1).

The planes are never broken off from the network, which is marked by a center-less, branching arrangement of "sectors". It was in the vertical spaces sandwiched between the planes where everything was to happen, and where design would practically vanish, along with the distinction between artist and non-artist. This was the living space, and it was meant to be infinitely configurable by its users. As de Zegher puts it (2001, p. 10):

The inhabitants drift by foot though the huge labyrinthine interiors, perpetually reconstructing every aspect of the environment by changing the lighting and reconfiguring the mobile and temporary walls. For this homo ludens, social life becomes architectural play and the multiply interpretable architecture becomes a shimmering display of interacting desires - a collective form of creativity, as it were, displacing the traditional arts altogether.

The project was never realized, but was extensively modeled by Constant in elaborate small-scale constructions which still give architects pause today. In them intricate cabling, often fanning out from tall pillars, suspends carefully fitted plexiglass, enclosing the living space, above mostly featureless white paper, that denoting the ground. But as Wigley has noted, what actually happens in this living space is always blurry and undefined, the indeterminacy of its representation in Constant's models and drawings set against the exacting and specific demonstrations of how the space is made possible. "Inside, things are always blurry ... Constant continually blurs both the play of desire, which cannot be specified without blocking it, and the support of that play, which cannot be represented without it being mistaken for frozen play" (2001, p. 50).

It is not a surprise that such an ambitious and utopian project relies on no longer fashionable assumptions about technology and production. Constant imagined - as have many going back to Karl Marx (and forward to Star Trek) - a fully automated system of production, 


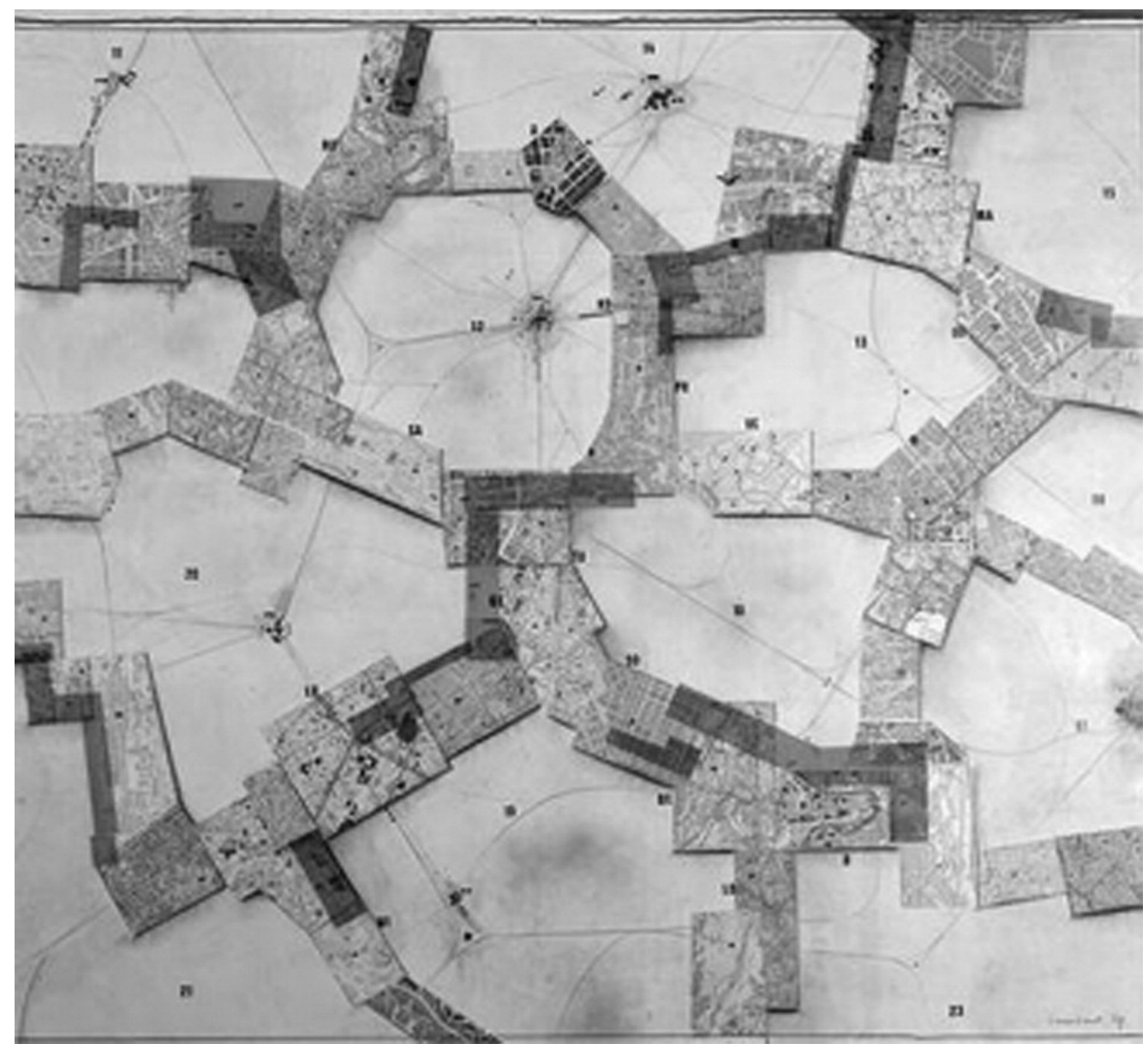

one that would free individuals from having to act for any other reason than to fulfill their creative impulses. In New Babylon, all of this automated production took place underground, the only evidence of the machinery being the small points (perhaps for ventilation) that would protrude very slightly above ground (often at the center of the open spaces in the branching network of sectors). As Wigley puts it, “New Babylon is a seemingly infinite playground. Its occupants continually rearrange their sensory environment, redefining every microspace within the sectors according to their latest desires. In a society of endless leisure, workers have become players and architecture is the only game in town, a game that knows few limits" (2001, p. 27).

Thus is Karl Marx reconciled with Johan Huizinga; to play is to be creative is to be human, with creativity standing in for Marx's picture of the human as the maker. In New Babylon, homo faber and homo ludens are one under the rubric of creativity. In the symposium interview of 1999, Constant outlines his ideas in this area specifically (De Zegher and Wigley 2001, pp. 24-25):

Huizinga, and his homo ludens, was thinking about a state of mind, not about a new kind of humanity; of human being, but in a certain sense a state of mind, of certain temporary conditions of human beings. For instance, when you are at a carnival, a feast, a wedding party. Temporarily you become the homo ludens, but then the next day you can be the homo faber again. He has to earn his pay. Marx... says creativity is a state of mind. A man cannot always be a painter. He is only a painter when he paints.... That is close. I have always tried to reconcile those two points of view, those visions of Marx ... and Huizinga.

New Babylon, in a sense, was about designing for play, because play was for Constant the essence of creative human activity. This brings us to the role of the child in this conception of play. The child represented creation in several important ways for Constant, and for several movements of which he was a part, including the Dutch Experimental Group (founded in 1948), COBRA, and the Situationist International. For these movements the social order itself was the target for radical reconfiguration. Artists, as a category, were complicit in an exploitative social order, and thus the distinction between artists and non-artists had to be broken down. One way this was done was by the exhibiting of children's drawings alongside those of members of the movement, something COBRA did in the early 1950s (see Wigley 2001, pp. 34-36). This concept of the value of children's playful work was tied to an idea about the primitive, in the sense of the original or primal, where children's creativity was taken as an instance of purely human creativity before the twisting and confining influence of social institutions.

But this conceptualization of the child and creation had moral overtones as well in postwar Europe. The first question asked of Constant at the symposium interview was about this connection to the art of the 
child in his and his cohort's work, and Constant's reply begins with an articulation of the above point about the primitive, but then he elaborates further (De Zegher and Wigley 2001, p. 15):

Not exactly the child. Not only the child, but going back to the origins of creation - of artistic creativity. We cannot think of COBRA without thinking of the situations we were in after the war, the situation of complete emptiness.... Especially in Holland it was nearly nothing for these young artists, so that we turned to what was the only thing that looked at least like creation, like spontaneous expression of humanity.

The vast destruction of the war, and its moral horrors, left thinkers like Constant in postwar Europe reaching for a source for (re)creation that would be outside the received social order, exemplify the essentially human, and thereby recoup moral ground. Huizinga's legacy for Europe, at least for these movements generally and New Babylon specifically, was a particular conception of play, one that elevated the child and focused on the unschooled, non-institutional play that distinguished childhood.

For Constant it was not enough to valorize this form of creativity. He sought to actively bring about a new urban landscape which would foster it. And herein lay a contradiction, for to do that Constant had to seize some degree of artistic, in this case architectural, authority. His plans for New Babylon began at almost the same time that he co-founded the Situationist International, in 1958, but he left that same organization in 1959, frustrated by what he saw as a resistance to applying the ideas of the movement on the part of Guy Debord and others. The problem, as he saw it, was one of taking an active role in prompting the kind of society they wanted; a question of the authority that, in a way, makes social policy possible. As Constant put it (De Zegher and Wigley 2001, p. 25), “It's not enough to say that everybody is an artist. I have said this long before Beuys, other people have even before me - the surrealist movement, for instance. What is important is to figure out how this creativity, this sleeping creativity ... can be woken up."

\section{Constant had by that time already had experience} in attempting to architect play. After COBRA disbanded, Constant joined Aldo van Eyck in designing playgrounds in Amsterdam. In New Babylon, Constant continued in the effort of designing for play. "Children's creativity remained Constant's model, but its products were no longer to be simply imitated. As with the playgrounds, it was a matter of making spaces for play rather than reproducing its patterns. Like van Eyck, Constant used a highly controlled abstract geometry to facilitate an uncontrolled play" (Wigley 2001, p. 46). This was "designed confusion" (2001, p. 31) or, as I would put it, contrived indeterminacy.

In this way Constant embarked in his distinctive way on a program to find a means of governance that we might call post-bureaucratic. In rejecting the existing modern bureaucratic institutions that had defined the social order (and were implicated in the horrific war), he and his contemporaries found an alternative in childlike play. But Constant took a further step and sought to work through how to contrive such play, how to employ controlled design that would prompt uncontrolled play within the spaces of New Babylon. Such play would embody a contradiction. It would be self-governing, to the extent that the use of the spaces in New Babylon was completely under the control of its residents. But this of course elides the role of the designer, or anyone with access to control over the conditions of the domain as a whole. Just as only the tips of the automated machinery can be glimpsed above ground everywhere, if one were to look, so the social position of the maker, homo faber of a different order, is everywhere and nowhere (Figure 2).

Play for Constant in his war-ravaged Europe stood as a productive and morally innocent, childlike force, one that could nonetheless through design be prompted and contained in order to remake the urban (in fact, all) landscape.

\section{LINDEN LAB AND SECOND LIFE}

Catherine de Zegher, director of the Drawing Center during the 1999 symposium, drew out some of the implications of New Babylon in an era of networked technologies. While the web had already arrived, Second Life was still four years away (in fact, its founder Philip Rosedale had at that point just quit his job as the Chief Technology Officer of Real Networks in order to found Linden Lab). But de Zegher's comments seem prophetic, if at times they seem to overstate the parallels between New Babylon's theoretical lack of constraints and the seemingly unconstrained web (de Zegher 2001, p. 10):

Prefiguring the current debate about architecture in the often placeless age of electronics, Constant seems to have conceived of an urban model that literally envisaged the World Wide Web. In the network of sectors in New Babylon, one configures his or her own space and can wander in an unobstructed way from to site, without limits. In this respect, Constant's project represents the spatialization of a virtual world, where people can move, meet, and interact anytime, anywhere. As an unlimited communication system, the work is as radical as ever.

This could almost serve as a mission statement for Second Life, which, like New Babylon, sought to bring everyone (indeed, in aspiration, everyone on the planet Earth) together in a space where they would have freedom to play in an unconstrained fashion and access to the tools for creation. In a way, Second Life is New Babylon, or an attempt as close as we may ever see.

What is Second Life? It is a virtual world, just as de Zegher put it, but now that term has come to denote a category of persistent online spaces for social interaction. While the first ones were text-based, the largest now have three-dimensional graphics, and users participate in them through their avatars, representations of their bodies in this virtual space. Many of them are games in a foundational sense, that is they have shared and established game objectives 
(such as World of Warcraft, Ultima Online, Lineage II, or Warhammer Online). World of Warcraft is the largest, claiming more than 12 million active subscribers. Others are sometimes called "social virtual worlds", and do not have shared and established game objectives. Second Life is one of these and has, by some accounts, upwards of 500,000 active users. Second Life's distinctive feature is that all users have access to 3-D modeling, scripting (programming), and texture-mapping "tools", ones that allow them to make interactive objects in the world. Just as important, users own the intellectual property rights to their creations (which cost next to nothing to reproduce), and can control how they are distributed to other users, including the possibility of market transactions in the in-world currency, Linden dollars. When I began doing research at Linden Lab in December 2004, approximately 13,000 users had created accounts in Second Life - small by the standards of the virtual world industry (at the time the original Lineage, a game primarily popular in East Asia, boasted over two million users worldwide), but this number was beginning to rise at an increasing rate, and by the end of 2005 they had over 120,000 registered users.

Governance of Second Life is supposed to be minimal as well. While Linden Lab provides the landscape in the world, creating continents and countless small islands, what is built on this virtual land is left almost entirely up to the users. This style of governance shares with Constant's efforts the distinction between those acting freely within a domain and those with the authority or access to architect that domain in its entirety, but when we explore the ideological and practical roots of Linden Lab's approach, the path could not be more different from Constant's Marxian views. Recent work has charted how some of the most important developments in computing and networking technology in the United States were inextricably linked to political and more broadly ideological interests. Works by journalists (Kidder, 1981; Hiltzik, 2000; Waldrop, 2001; Markoff, 2005) and, more recently, academics (Thomas, 2003; Turner, 2006) are helpful in filling out the culturo-historical landscape from which computers emerged, particularly in the San Francisco Bay area. Specifically, these works reveal how the development of these technologies and their makers' aspirations for them were inextricably linked to general attitudes to authority that characterized the postwar period.

In these works there is a common theme: among this emerging culture one finds a remarkable and mutually confirming combination of a deeply held skepticism toward "top-down" decision-making - with a corresponding resistance to (and even resentment of) the institutional control of technology - and a deep faith in the ability of technology to provide solutions when made widely available. The contrast here is with computing as it existed in institutions through the 1960s: mainframe computing demanded specialized and controlled access to the most powerful tool in an institution, and its enduring image is that of the mainframe in the glass room, accessible only by a priesthood of those empowered to tend it. The attitude that arose in reaction against this image, these books suggest, reflects the anti-establishment politics of the period and found purchase in the distinctive disposition of engineers toward new technologies, corporate organizations, and a particular version of libertarianism. As Coleman put it (2004, pp. 511-512):

Programmers over decades of intense interaction come to viscerally experience the computer as a general purpose machine that can be infinitely programmed to achieve any task through the medium of software written by humans with a computer language. The technological potential for unlimited programmable capabilities melds with what is seen as the expansive ability for programmers to create. For programmers, computing in a dual sense, as a technology and as an activity, becomes a total realm for the freedom of creation and expression.

The issue of creation and engineering is central to Linden Lab's project in particular, as the making of the world of Second Life stands in a strange and mutually constructive relationship to the making in the world on the part of its users.

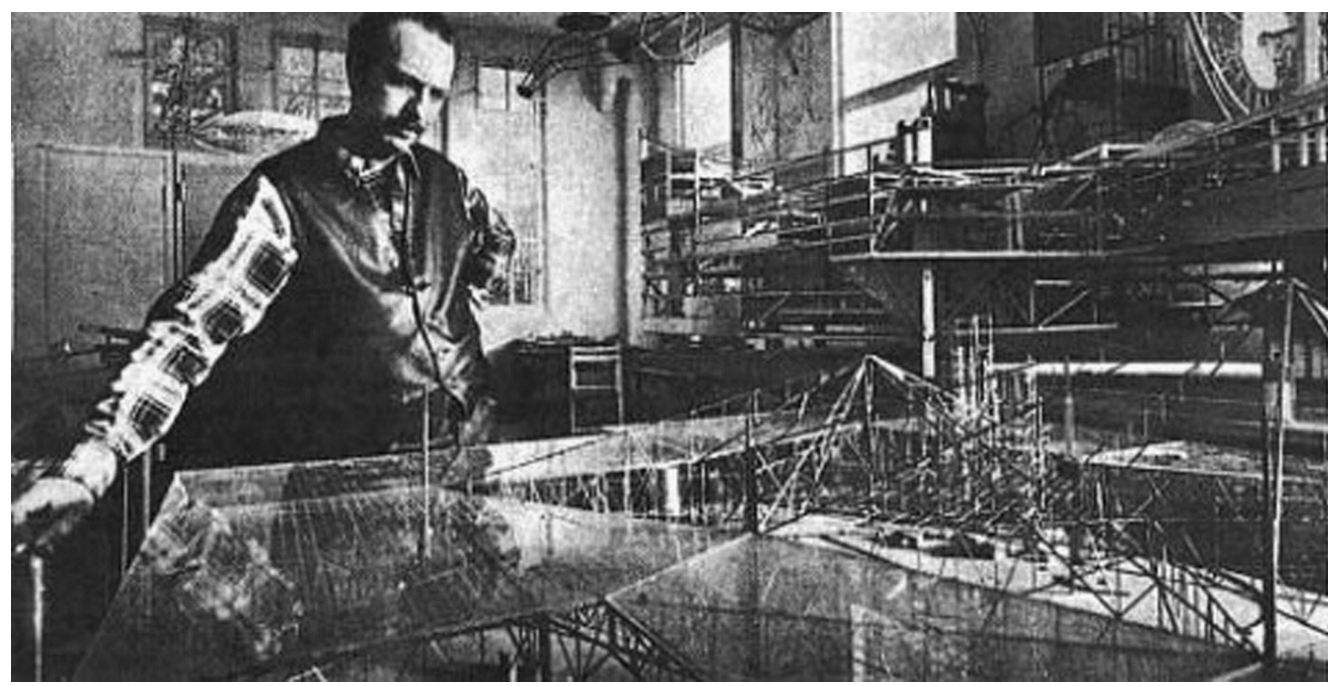

Figure 2. 
But there is another strand of this thought that has a direct bearing on Linden Lab, and it brings us back to the issue of play and games: emergent properties and how legitimate they are as a basis for self-governance. A new style of work practice came out of the Second World War and the cold war to follow, with that era's constant demands on the United States to innovate in a number of areas (the atomic bomb being the most famous example). In places like MIT's Radiation Lab, members of the military, industry, and academe had to find a way to work together despite the fact that no single vertical institution governed them all (Turner, 2006). The successes produced by such collaborations resonated with ideas put forth by some of their members. Norbert Wiener and Julian Bigelow, through war-related research on systematizing antiaircraft weaponry, had begun to apply the metaphor of computing on a grand scale to humans and their society. As Turner writes, “Wiener and Bigelow offered up a picture of humans and machines as dynamic, collaborating elements in a single, highly fluid, socio-technical system. Within that system, control emerged not from the mind of a commanding officer, but from the complex, probabilistic interactions of humans, machines, and events around them" (2006, p. 21).

We see already a contrast with the European scene, as many historians have noted. Whereas Europe was left ravaged and broken by the Second World War, the United States emerged confident and masterful, the new superpower on the world stage. It should not surprise us, then, that a tracing of ideas about play as they influenced Second Life has a very different tenor. For an understanding of Linden Lab, one effect of the rise of this thinking about socio-technical systems and controls was the implicit legitimacy that such emergent effects seemed to have. The suggestion (and it is one that can be traced all the way back to Adam Smith's "invisible hand") is that the emergent properties of complex interactions enjoy a certain degree of rightness just by virtue of being emergent. The emergent effects that complex spaces like virtual worlds generate depend on this open-endedness, the lack of determinacy in the environment and participants' actions in it, and this open-endedness is to a certain extent contrived.

In thinking about how these ideas connect to the American conversation about urbanism specifically, it becomes worthwhile to note the link to the ideas of Jane Jacobs, who lodged her own strong critique of modernist urban planning in her landmark The death and life of great American cities (1961). Jacobs argued that great cities, like New York, were great because of how the contingent and at times inefficient led to a social vitality. The jumble of inherited practices, architectural styles, and larger projects (subway liens) threw people together in a mix of circumstances. Here, too, is a faith in the emergent, in this case the aggregate and historical processes that generate governance organically. The targets of Jacobs's critique were in some ways the same as Constant's and the Situationists': those presuming a top-down form of rationalized control was the best hope for achieving social goods. Jacobs's book and its ideas circulated around Linden Lab, and formed the touchstone for a number of initiatives that sought to promote Second Life's self-governance (for an extended discussion of the influence of Jacobs's ideas on Linden Lab, see Malaby, 2008). But the contradiction is not hard to see. Jacobs celebrated the uncontrived, and showed up the folly of the modernist project in aspiring to a kind of total planning. Linden $\mathrm{Lab}$, however, was engaged in the attempt to contrive this vital open-endedness, just as Constant was; this was not top-down rationalist planning, but it bespoke the same will to govern the conditions for action. And just as Constant departed from the Situationists over the issue of the imperative to act from an authoritative position, even in a post-bureaucratic fashion, so we find a similar tension in Linden Lab's embrace of Jacobs's ideals in the midst of its own deep authority.

But we can go further, and recognize a different kind of play in this formulation of socio-technical systems. Ken Kesey and the Merry Pranksters, staples of the 1960s counterculture and close to Stewart Brand of the Whole Earth Catalog, made use of games in their efforts to overcome vertical authority. As Turner describes (2006, p. 65):

[Ken] Kesey and the Pranksters turned to various devices to distribute and, ostensibly, level... power. One of the devices was a simple spinner. The Pranksters regularly played a game in which a number of them would sit in a circle. Someone would spin the spinner, and whoever it pointed to would then have full power over the group for the next thirty minutes.

Another example is a game they played with the $I$ Ching; a person would toss a set of coins and then consult the book for a correlating bit of text, which would then be taken as guiding action. Thus, the Merry Pranksters sought to invest power in game-like processes, aided by technology. It was game design that they engaged in - the combining of constraining rules and sources of indeterminacy (the coins, the spinner). Kesey and Pranksters had only familiar, "analog" sources of stochastic contingency ready to hand, the accessible computers that followed soon after allowed for a vast multiplication of both controls and contingencies.

The implication, I suggest, is that play for both projects was central to the conception of a post-bureaucratic form of governance. But whereas play in Europe for projects like Constant's was imbued with the child and the primal, in the United States, for an important strand of thinking and practice as related to technology, play was imbued with notions of individual mastery over a complex system. A core idea exemplified in Brand's Whole Earth Catalog was of an individual, amid a complex system of affordances, pursuing enlightened self-interest, and contributing to collective and emergent effects that were thereby legitimate. $0 n$ this view, authority is collectively generated out of many individuated acts of agency within a system. With the spinner and I Ching games the Pranksters sought to architect that circumstance. That is, they sought not only to provide "tools" to people in the unbounded 
world of the everyday, but to set up a circumstance of constraints and possibilities within which that individual pursuit of enlightened self-interest would take place. But something very important changes when it is no longer simply the provision of tools which is the aim, but rather the broader project of contriving (and providing) the conditions - the system, in a sense - in which those affordances are encountered and used.

This line of thinking about play as a kind of individual mastery can be traced to an important thinker about play who developed Huizinga's ideas on the American side of the Atlantic, Mihalyi Csikszentmihalyi (1990). For Csikszentmihalyi, play can be found wherever people face an ongoing mixture of pattern and unpredictability that demands a practiced mastery of performance (what he calls "flow), such as for the factory worker who happens to confront the properly engaging mixture of constraint and (perhaps dangerous) possibility in manipulating multiple machines and objects. Practiced makers of cedar shingles, for example, deftly handle the slight variations in every piece of wood that comes their way as they coordinate their bodily movements in extremely close proximity to two open and spinning saws. Csikszentmihalyi's focus on a state of mastery aligns well with the ideas of Wiener and others who saw individuals as active and performative participants in complex systems. To a certain extent, then, when many Lindens imagined their users, they imagined game-players in this way. They were gamers in a highly individualistic sense. For many Lindens a game constituted, at root, a challenge to an individual to act within an open-ended system, whether that game involved other players or not.

Both of these projects, appearing in such different times and places, reveal themselves as not so different in their final aspirations, or so different in the hopes they invested in productive play. But the productive play for each was so different, coming to these designers through such vastly different paths, that we are left reconsidering how universal and transhistorical the idea of play could possibly be. Instead we may find it more useful to consider play in a way similar to how William James saw religious experience, never found in some universal form but rather appearing in great variety, reflecting the myriad of times and places for human life (James, 1902). Here, the turn to a primal and innocent child's play in Europe seems a completely different move from the appeal to a masterful, individual gamer in the United States, yet both were held to be productive, and embodied the hopes of designers for generative action in postbureaucratic eras.

\section{REFERENCES}

Brand, Stewart (Ed.). (1969). Whole Earth catalog: Access to tools. Menlo Park, CA: Portola Institute.

Borden, Iain, \& McCreery, Sandy (Eds.). (2001). New Babylonians: Contemporary visions of a Situationist city. Seattle, WA: Academy Press.
Buchloch, Benjamin. (2001). A conversation with Constant. In The activist drawing: Retracing Situationist architectures from Constant's New Babylon to beyond (pp. 15-26). Cambridge, MA: MIT Press.

Coleman, Gabriella. (2004). The political agnosticism of free and open source software and the inadvertant politics of contrast. Anthropological Quarterly, 77(3), 507-519.

Csikszentmihalyi, M. (1990). Flow: The psychology of optimal experience. New York: Harper \& Row.

De Certeau, Michel. (1984). The practice of everyday life. Translated by Steven Rendall. Berkeley: University of California Press.

De Zegher, Catherine. (2001). Introduction. In The activist drawing: Retracing Situationist architectures from Constant's New Babylon to beyond (pp. 9-15). Cambridge, MA: MIT Press.

De Zegher, Catherine, and Wigley, Mark (Eds.). (2001). The activist drawing: Retracing Situationist architectures from Constant's New Babylon to beyond. Cambridge, MA: MIT Press.

Hiltzik, Michael A. (2000). Dealers of lightning: Xerox PARC and the dawn of the computer age. New York: Collins.

Huizinga, Johan. (1955). Homo ludens. New York: Beacon Press.

Jacobs, Jane. (1961). The death and life of Great American cities. New York: Random House.

James, William. (1902). The varieties of religious experience: $A$ study in human nature. New York: Modern Library.

Kidder, Tracy. (1981). The soul of a new machine. Boston: Little, Brown.

Levy, Steven. (1984). Hackers: Heroes of the computer revolution. New York: Doubleday.

Malaby, Thomas M. (2009). Making virtual worlds: Linden Lab and Second Life. Ithaca, NY: Cornell University Press.

Markoff, John. (2005). What the dormouse said: How the 60s counterculture shaped the personal computer. New York: Viking Adult.

Thomas, Douglas. (2003). Hacker culture. Minneapolis: University of Minnesota Press.

Turner, Fred. (2006). From counterculture to cyberculture: Stewart Brand, the Whole Earth Network, and the rise of digital utopianism. Chicago: University of Chicago Press.

Turner, Victor. (1969). The ritual process: Structure and antistructure. New York: Walter de Gruyter.

Waldrop, M. Mitchell. (2001). The dream machine: J.C.R. Licklider and the revolution that made computing personal. New York: Viking Adult.

Wigley, Mark. (2001). Paper, scissors, blur. In The activist drawing: Retracing Situationist architectures from Constant's New Babylon to beyond (pp. 27-56). Cambridge, MA: MIT Press.

\section{CORRESPONDENCE}

Thomas M. Malaby, Department of Anthropology, University of Wisconsin-Milwaukee, PO BOX 413, Milwaukee WI 53201, USA.

E-mail:malaby@uwm.edu

ISSN 1749-3463 print/ ISSN 1749-3471

DOI: 10.1080/17493460902942204

(C) 2008 Artifact 